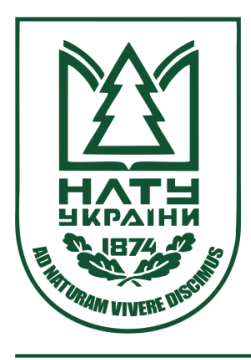

Науковий вісник НлтУ України Scientific Bulletin of UNFU

https://nv.nltu.edu.ua

https://doi.org/10.15421/40280825

$@ \bowtie$ Correspondence author

Article received $10.10 .2018 \mathrm{p}$.

Article accepted 25.10.2018 p.

O. M. Gerasimov

удк 630*5

\title{
ВІЗУАЛЬНЕ ДЕШИФРУВАННЯ ПРИРОДНИХ ЗМІН ЛІСІВ ДП "ЧИГИРИНСЬКЕ ЛІСОВЕ ГОСПОДАРСТВО" ЗА СУПУТНИКОВИМИ ЗНІМКАМИ LANDSAT
}

\begin{abstract}
Встановлено використання супутникових знімків у лісовому господарстві, зокрема дешифрування лісових масивів із використанням супутникових знімків. Головною метою цієї роботи є створення умов, які б полегшили ведення лісового господарства. Дослідження, проведені під час роботи над матеріалом, дають змогу швидко виявити масштаби пошкодження та вжити необхідних заходів. Під час проведення досліджень було використано знімки лісового масиву з супутників Landsat. Результатом дослідження стало поєднання супутникових знімків із лісопатологічним журналом підприємства, що дало змогу візуально дешифрувати ділянки, пошкоджені шкідниками. Також для візуального дешифрування лісового масиву, пошкодженого пожежею, використано матеріали з журналу реєстрації лісових пожеж. Результати проведеного дослідження можна використати для рекогносцирувального нагляду за насадженнями, враховуючи біологію того чи іншого шкідника. Проведені дослідження показують, що використання дистанційного зондування Землі в лісовому господарстві значно спрощують роботи, пов'язані з охороною та захистом лісу. З'ясовано, що використання безкоштовних супутникових знімків та програмного забезпечення дає змогу відстежувати стан насадження до та після впливу певних негативних факторів, а також прогнозувати заходи для боротьби з наведеними вище пошкодженнями. Виявлено, що дистанційне зондування Землі значно покращує якість виконання робіт з охорони та захисту лісу.
\end{abstract}

Ключові слова: геоінформаційні технології; дистанційне зондування землі; дешифрування; супутникові знімки.

Вступ. Сучасні геоінформаційні технології забезпечують значні можливості у сфері збору, оброблення, аналізу та візуалізації як просторових даних взагалі, так i даних дистанційного зондування. До матеріалів дистанційного зондування належать будь-які дані, отримані за допомогою сенсорів, сканерів, оптичних пристрої, радарів та фотоапаратів, установлених на супутниках, літаках тощо (Zavada, 2007; Repozitorii, 2016).

На сьогодні можна отримати практично будь-яку інформацію відносно різних природних або антропогенних об'єктів та процесів. Сучасні супутники надають можливість отримувати дані з просторовим розрізненням 30 м (Landsat) у термін до 48 год.

У практиці лісового господарства тривало використовують матеріали дистанційних досліджень Землі. на підстаі фотограмметричної інформації аерофотознімків проводять лісову інвентаризацію, фенологічні спостереження, моніторинг стану лісів та навколишнього середовища (Rekomendatsii, 2001; Proekt, 2014).

Сучасне програмне забезпечення дає змогу використовувати дистанційне зондування землі, щоб стежити за динамікою таксаційних показників, впливом стихійних явищ та враження лісових масивів шкідниками (Zavada, 2007; Rekomendatsii, 2001).

Методика дослідження грунтується на виявленні динаміки таксаційних показників за допомогою супутникових знімків, отриманих у різний період. Для такого аналізу використано безкоштовне програмне забезпе- чення (GisLab, 2017; Rekomendatsii, 2001).

Для досліджень опрацьовано безкоштовні супутникові знімки з супутника Landsat та програмне забезпечення QGIS. Додатково було використано матеріали лісопатологічного обстеження та визначено квартали та ступінь пошкодження насадження шкідником (USGS, 2018; GisLab, 2017).

Результати дослідження. Соснові насадження Притясминської гряди штучно сформовані в 50-х роках XX ст. у надзвичайно бідних, екстремальних для росту i розвитку сосни звичайної умовах. Природна дефоліація цих насаджень $є$ відхиленням від норми для соснових насаджень України. Хвоя дерев природно ослаблених $є$ кормом гусениць комплексу хвоє-гризунів. Зважаючи на це, важко прогнозовані спалахи розвитку небезпечних шкідників хвоє-гризунів, починаючи з кінця 80-х років минулого століття, стали системними. Так, у 2013 р. насадження сосни піддалися об'їданню сосновою совкою на площі 457 га, про що свідчать записи в лісопатологічному журналі. Об'їданням хвої були вражені 6; 9; 14-16; 54-57 квартали Трушівського лісництва. Після об'їдання в насадженні різко знизилися таксаційні показники, що призвело до зниження приросту. За вчасного виявлення таких осередків пошкоджень можливо вчасно запропонувати заходи для усунення їх шкоди. Це можливо за допомогою супутникових знімків із супутника LANDSAT (рис. 1-2). Можна спостерігати за осередком виникнення шкідників та прогнозува-

\section{Інформація про авторів:}

Герасімов Олександр Миколайович, аспірант. Email: gerasimov00@ukr.net

Цитування за ДСту: Герасімов О. М. Візуальне дешифрування природних змін лісів Дп "Чигиринське лісове господарство" за супутниковими знімками Landsat. Науковий вісник НЛтУ України. 2018, т. 28, № 8. С. 129-131.

Citation APA: Gerasimov, O. М. (2018). Visual interpretation of natural damages in Chigirin forestry SE on the basis of landsat satellite images. Scientific Bulletin of UNFU, 28(8), 129-131. https://doi.org/10.15421/40280825 
ти частку об'їдання хвої сосни. На супутниковому знімку видно, що осередок об'їдання знаходиться у Трушівському лісництві ДП "Чигиринське лісове господарство". Квартали, вражені сосновою совкою, на знімку відображені бурою плямою. Частка об'їдання становить 50 \%. Враховуючи викладений вище матеріал, можна зробити висновок, що за допомогою ДЗ3 та ГІС можна спостерігати за виникненням шкідників та хвороб у лісових масивах за наявності свіжих супутникових знімків та спеціального програмного забезпечення.

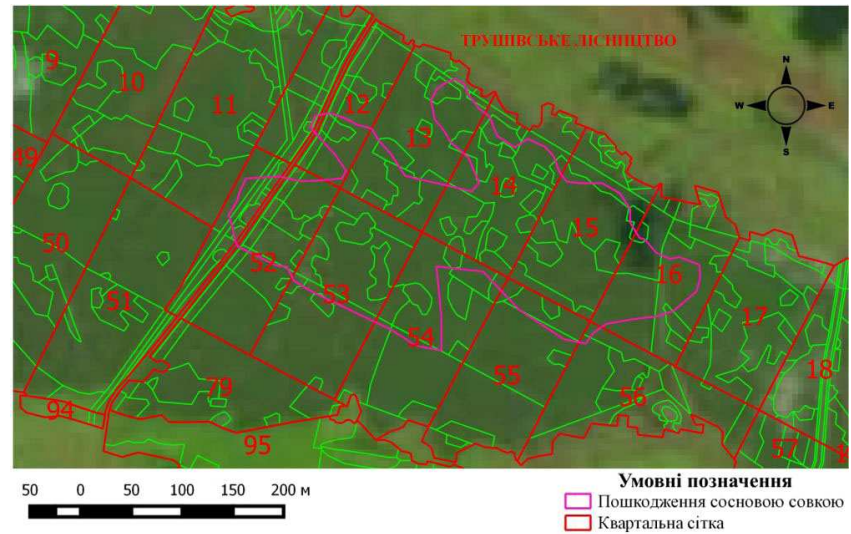

Рис. 1. Супутниковий знімок штучних насаджень сосни звичайної в 2010 p.
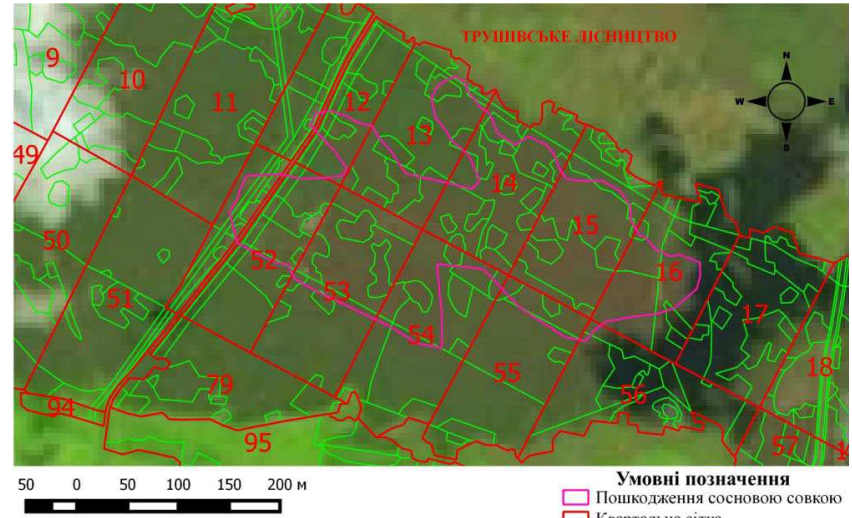

$\square$ Пошкодження со

Рис. 2. Супутниковий знімок об'ідання штучних насаджень сосни звичайної сосновою совкою у 2013 р.

У 1999 р. штучні насадження сосни звичайної Притясминської гряди були вражені лісовою пожежею на площі 120 га. Відповідно до книги обліку лісових пожеж контур пожежі, знаходився у кварталах 21-23; 3638 Чигиринського лісництва, про що свідчать космічні знімки супутника Landsat, та покладений на нього шар із квартальною сіткою лісництва (рис. 3-4). Дерева були пошкоджені до ступеня припинення росту, що спонукало до їх звалювання та висаджування нових молодих дерев. Упродовж шести років лісокультурної кампанії повністю заліснити площу пройдену пожежею, так і не вдалося. У 2006 р. цю саму ділянку було вражено пожежею повторно, але вогонь охопив меншу площу, про що свідчать записи в книзі обліку лісових пожеж.

За допомогою супутникових знімків можна побачити стан насадження до пожежі в 1999 р. та після пожежі в 2000 р. Приклади супутникових знімків наведено нижче. Супутникові знімки використано із супутника Landsat. Наведені приклади показують на широкі можливості використання супутникових знімків для візуального дешифрування природних пошкоджень лісового вкриття, які можна використати для оцінки їх обсягів та динаміки.

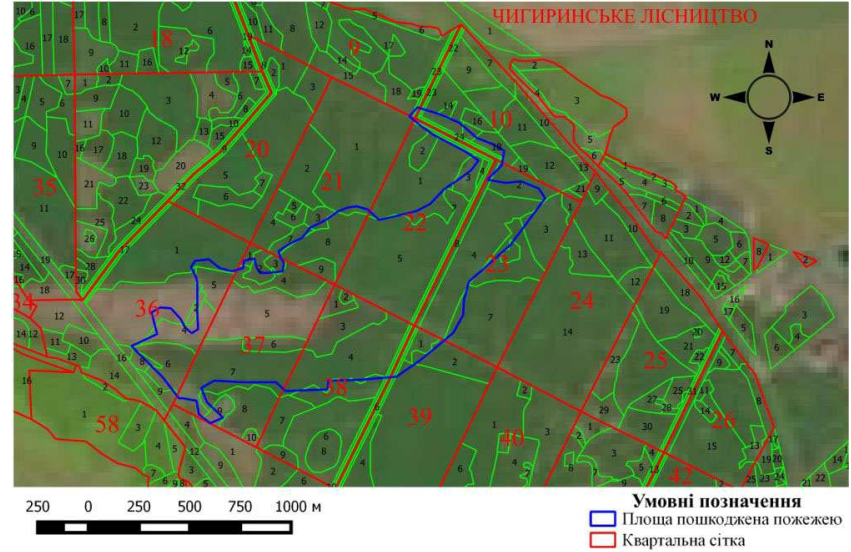

Рис. 3. Стан штучних соснових насаджень до виникнення пожежі

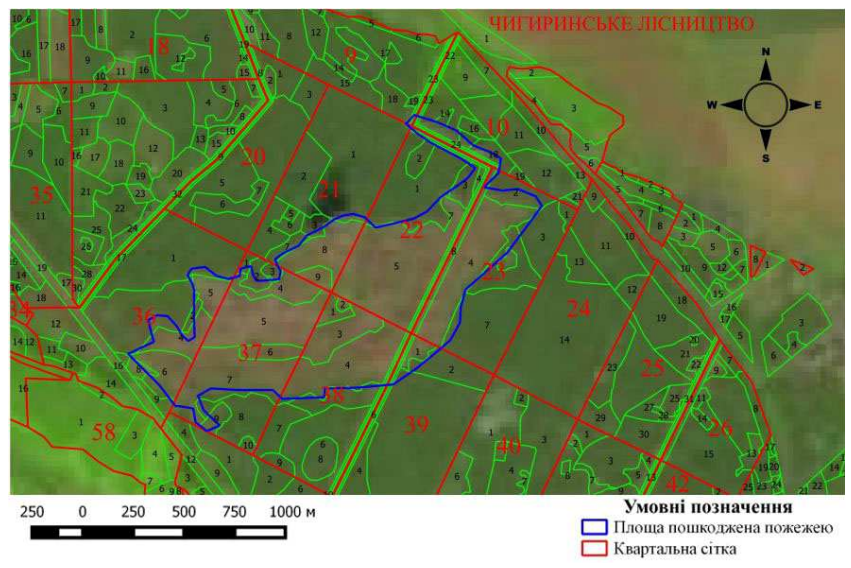

Рис. 4. Стан штучних соснових насаджень після пожежі

Висновок. Отже, за допомогою відповідного програмного забезпечення та супутникових знімків можна стежити за змінами стану лісових насаджень. Також супутникові знімки дають змогу слідкувати за змінами, які відбуваються в насадженнях до та після певних впливів чи то стихійних явищ, хвороб та шкідників, чи антропогенних чинників. Сучасне програмне забезпечення дає змогу зробити дешифрування знімків, що покращує та полегшує певні види робіт у лісовому господарстві, починаючи від зміни таксаційних показників i закінчуючи впливом певних явищ, які були зазначених вище. Також за допомогою супутникових знімків можна проводити моніторинг лісових насаджень, які були пошкоджені шкідниками, хворобами та пожежами, і планувати комплекс лісогосподарських робіт.

\section{Перелік використаних джерел}

GisLab. (2017). Opyt klassifikatcii kosmosnimka Landsat s pomoshhiu Semi-Automatic Classification Plugin v QGIS. Retrieved from: http://gis-lab.info/qa/landsat qgis scp.html. [In Russian].

Proekt. (2014). Proekt orhanizatsii ta rozvytku lisovoho hospodarstva DP "Chyhyrynske lisove hospodarstvo" Cherkaskoho oblasnoho upravlinnia lisovoho ta myslyvskoho hospodarstva. Irpin, 244 p. [In Ukrainian].

Rekomendatsii. (2001). Rekomendatsii z vedennia lisovoho hospodarstva $v$ Prytiasmynskykh borakh. Kharkiv: UkrNDILHA. [In Ukrainian].

Repozitorii. (2016). Tcifrovoi repozitorii KhNUGKh im. A. N. Beketova privetstvuet Vas! Retrieved from: http://eprints.kname.edu.ual. [In Russian].

USGS. (2018). Science for a changing world. Retrieved from: https://earthexplorer.usgs.gov/

Zavada, M. M. (2007). Lisova entomolohiia. Kyiv: KVITs, 216 p. [In Ukrainian]. 


\section{ВИЗУАЛЬНАЯ ДЕШИФРОВКА ПРИРОДНЫХ ИЗМЕНЕНИЙ ЛЕСОВ ГП "ЧИГИРИНСКОЕ ЛЕСНОЕ ХОЗЯЙСТВО" ПО СПУТНИКОВЫМ СНИМКАМ LANDSAT}

\begin{abstract}
Установлено использование спутниковых снимков в лесном хозяйстве, в частности дешифровки лесных массивов с использованием спутниковых снимков. Главной целью данной работы является создание условий, которые бы облегчили ведение лесного хозяйства. Исследования, проведенные во время работы над материалом, дают возможность быстро выявить масштабы повреждения и провести необходимые мероприятия. При проведении исследований использованы снимки лесного массива со спутников Landsat. Результатом исследования стало сочетание спутниковых снимков с лесопатологическим журналом предприятия, что позволило визуально дешифровать участки, поврежденные вредителями. Также для визуального дешифрирования лесного массива, поврежденного пожаром, использовались материалы из журнала регистрации лесных пожаров. Результаты проведенного исследования можно использовать для рекогносцировочного надзора за насаждениями, учитывая биологию того или иного вредителя. Проведенные исследования показывают, что использование дистанционного зондирования Земли в лесном хозяйстве значительно упрощают работы, связанные с охраной и защитой леса. Установлено, что использование бесплатных спутниковых снимков и программного обеспечения дает возможность отслеживать состояние насаждения до и после воздействия определенных негативных факторов, а также прогнозировать меры по борьбе с выше приведенными повреждениями. Выявлено, что дистанционное зондирование Земли значительно улучшает качество выполнения работ по охране и защите леса.
\end{abstract}

Ключевые слова: геоинформационные технологии; дистанционное зондирование Земли; дешифровка; спутниковые снимки.

O. M. Gerasimov

Ukrainian National Forestry University, Lviv, Ukraine

The usage of satellite images in forest management is presented in the article. The interpretation of forest stands on the basis of satellite images is provided. The main purpose of this work is the building of conditions that would facilitate forest management. Studies carried out during the work on the material allow quick identifying the extent of damage and carrying out the necessary activities. During the research of the forest massif the Landsat satellites images were used. The result of the study was the combination of satellite images with the forest pathological journal of the enterprise, which allowed visual identifying the sites damaged by pests. Some materials from the log of forest fires were also used for visual interpretation of the forest massif damaged by fire. The results of the study can be used for reconnaissance overseeing the plantings, taking into account the biology of pests. Studies have shown that the use of remote sensing of the Earth in forestry significantly simplifies the work associated with the protection and defense of forests. It has been found that the use of free satellite imagery and software enables monitoring the planting state before and after the impact of certain negative factors, and to predict measures to combat the above-mentioned damage. The remote sensing of the Earth is proved to significantly improve the quality of the work on protection and defense of the forest. It has been revealed that when using satellite images, it is possible to monitor plantings of pests damaged, illnesses and fires, if such damage leads to defoliation and is clearly visible on a satellite image. It has been shown that it is necessary to know the biology of the pest itself to identify it on the ground and on a satellite image for monitoring pests forests. It has been found that the use of satellite images in forestry to monitor forest plantations for the damage of their pests, diseases and fires requires appropriate software, as well as a digital map of the forest massif. Thus, forest fires are clearly visible on a satellite image, which allows determining the area of damage and facilitate the implementation of forestry work.

Keywords: geoinformation technology; remote sensing; image interpretation; satellite images. 